\title{
Garlic supplemented diet attenuates gentamicin nephrotoxicity in rats
}

\author{
Ilker Seckiner ${ }^{1}$, Omer Bayrak, Murat Can², A. Gorkem Mungan², N. Aydin Mungan ${ }^{3}$ \\ ${ }^{1}$ Department of Urology, University of Gaziantep, Gaziantep; ${ }^{2}$ Department of Biochemistry and \\ ${ }^{3}$ Department of Urology, University of Bulent Ecevit, Zonguldak, Turkey
}

\section{ABSTRACT}

Purpose: To demonstrate the effect of a 4\% pulverized garlic supplemented diet on the nephrotoxicity induced by gentamicin in rats.

Materials and Methods: Twenty four healthy male Wistar rats, weighing between 220 - 260grams, were divided into three groups. The rats were randomly assigned to either the gentamicin injection without garlic supplementation group (Group I, $n=8$ ), gentamicin injection with garlic supplementation group (Group II, $n=8$ ), and control group (Group III, $\mathrm{n}=8)$. Urine from the rats was collected and the volume $(\mathrm{mL})$, microalbumin (mg/L), creatinine (mg/dL), $\mathrm{Na}(\mathrm{mmol} / \mathrm{L}), \mathrm{K}$ (mmol/L), Cl (mmol/L), P (mg/dL), N-acetyl glucosamine (NAG) (U/L) and pH values were measured. Then urea $(\mathrm{mg} / \mathrm{dL})$, creatinine $(\mathrm{mg} / \mathrm{dL})$, total protein $(\mathrm{g} / \mathrm{dL})$ and cystatin $(\mathrm{mg} / \mathrm{L})$ values were measured for the blood samples obtained from tail veins.

Results: The median NAG value for the control group (52.050 U/L) was similar to value for Group II (56.400 U/L), which received gentamicin and the garlic diet. However, the median NAG value for Group I (77.030 U/L), which received gentamicin without garlic supplementation, was determined to be statistically significantly higher $(\mathrm{p}=0.010)$ than the value for the control group. In addition, the mean cystatin value for Group II (1.360 U/L) was found to be statistically significantly lower than the value for the Group I (2.240 U/L) ( $\mathrm{p}=0.015)$.

Conclusions: In this study we showed the effect of 4\% pulverized garlic supplemented diet for preventing nephrotoxicity induced by gentamicin in rats by using as parameters NAG in urine samples and cystatin C in serum samples.

\section{ARTICLE INFO}

Key words:

garlic, gentamicin,

nephrotoxicity, NAG, cystatin

Int Braz J Urol. 2014; 40: 562-7

Submitted for publication:

August 05, 2013

Accepted after revision:

September 24, 2013

\section{INTRODUCTION}

Aminoglycosides are a group of antibiotics that are frequently used for the treatment of severe gram-negative bacterial infections. However, the use of aminoglycosides, and especially gentamicin, are limited by their toxicity. Nephrotoxicity, otoxicity and neuromuscular blockage are their main side effects. Nephrotoxicity is observed in approximately $10-20 \%$ of patients using gentamicin (1). Gentamicin nephrotoxicity is characterized by tubular damage associated with tubular epithelial cell toxicity (1). It has been demonstrated in certain experimental animal studies that free oxygen radicals play a role in nephrotoxicity, and that the use of antioxidants such as vitamin $\mathrm{E}$ and selenium decreases nephrotoxicity $(2,3)$.

Numerous studies have been conducted regarding the antioxidant effects of garlic, and 
its beneficial effects have been described for various diseases (4). It has been reported that the antioxidant effects of garlic are associated with its ability to remove reactive oxygen species, to enhance endogenous anti-oxidation systems, and to inhibit the formation of lipid peroxides and the oxidation of low density lipoproteins (LDLs) (4).

It has been reported in recent studies that the antioxidant effects of garlic are derived from the active compounds S-Allylcysteine (SAC), S-Allylmercaptocysteine, Diallyl Disulfide and Diallyl Sulphide $(5,6)$. Pedraza-Chaverri et al. have described that the renal damage caused by gentamicin could be reduced with a garlic diet (7). Maldonado et al. have fed aged garlic extracts to rats administered with gentamicin, and determined that these extracts' antioxidant effects prevented the increase of carbonyl and nitrotyrosine levels in the renal cortex (8).

In this study, we aimed to demonstrate the effect of a $4 \%$ pulverized garlic supplemented diet on the nephrotoxicity induced by gentamicin in rats.

\section{MATERIALS AND METHODS}

Our study was started following the approval of the Local Ethics Committee. Twenty four healthy and active male Wistar rats, weighing between 220 - 260grams, were used within the context of this study.

\section{Study Groups}

Group I $(\mathrm{n}=8)$ : Experimental nephrotoxicity was induced by administering intraperitoneal gentamicin once daily at $120 \mathrm{mg} / \mathrm{kg} /$ day, according to the rats' body weight, for 14 days. During this period, the rats were provided with a standard laboratory rodent diet.

Group II $(\mathrm{n}=8)$ : Experimental nephrotoxicity was induced by administering intraperitoneal gentamicin once daily at $120 \mathrm{mg} / \mathrm{kg} /$ day, according to the rats' body weight, for 14 days. During this period, the rats were provided with a garlic supplemented diet, which was prepared by adding pulverized whole garlic cloves to the standard chow at a $4 \%$ proportion.
Group III ( $\mathrm{n}=\mathbf{8})$ : Intraperitoneal injections of $0.9 \% \mathrm{NaCl}$ were performed once daily to the rats in the control group for 14 days. The rats were then provided with a standard laboratory rodent diet for the remainder of the day.

All animals had free access to water and food. The consumption of total chow amount was noted for each group. The weight of each rat was controlled at the beginning and the end of the study.

On the 15th day, all rats were kept inside specially-designed metal containers. Owing to the special design of these metal containers, urine from the rats was collected in a reservoir located below. The volume $(\mathrm{mL})$, microalbumin $(\mathrm{mg} / \mathrm{L})$, creatinine $(\mathrm{mg} / \mathrm{dL}), \mathrm{Na}(\mathrm{mmol} / \mathrm{L}), \mathrm{K}(\mathrm{mmol} / \mathrm{L}), \mathrm{Cl}$ (mmol/L), P (mg/dL), N-acetyl glucosamine (NAG) $(\mathrm{U} / \mathrm{L})$ and $\mathrm{pH}$ values were measured for the samples collected from this reservoir.

Urea $(\mathrm{mg} / \mathrm{dL})$, creatinine $(\mathrm{mg} / \mathrm{dL})$, total protein $(\mathrm{g} / \mathrm{dL})$ and cystatin $(\mathrm{mg} / \mathrm{L})$ values were then measured for the blood samples obtained from tail veins.

\section{Laboratory}

Serum cystatin C (DAKO Cystatin C, Copenhagen, Denmark) and urine microalbumin (Roche, Basel, Switzerland)) concentrations were determined by latex particle enhanced immunoturbidimetry using an automated analyzer (Roche Integra 800, Basel, Switzerland). The serum and urine creatinine levels were detected by the kinetic Jaffé method. Blood urea values were measured by the kinetic method. Serum total protein and urinary phosphate levels were determined by the colorimetric method on Roche Integra 800. Urine, sodium, potassium and chloride were measured by indirect potentiometric method. NAG activity was determined by a commercially available kit (Diazyme Laboratories, San Diego, CA) using a Shimadzu UV 1601 spectrophotometer (Shimadzu Co, Kyoto, Japan). Urinary pH was measured by semi-quantitative paper strips (Macherey-Nagel, Duren, Germany).

\section{Statistical analysis}

"SPSS 11 for Windows" statistics software pack was used for statistical estimations. A non- 
parametric Kruskal-Wallis test and Mann-Whitney U test were used for group comparisons. The data were identified as medians and interquartile ranges (IR). A p-value lower than 0.05 was required for statistical significance.

\section{RESULTS}

No significant change was observed in the mean rat weights measured at the beginning and end of the study ( $p>0.05)$. The consumption of total chow amount was almost the same for each group $(3000 \pm 150 \mathrm{~g})(\mathrm{p}>0.05)$.

Urine Samples: A comparison of Groups I and II with Group III (the control group) with respect to urine volume, microalbumin, creatinine, $\mathrm{Na}, \mathrm{K}, \mathrm{Cl}, \mathrm{P}$ an $\mathrm{pH}$ levels revealed no statistically significant differences ( $p>0.05)$ (Table-1).

The median NAG value for the control group (Group III) (52.050 U/L, IR: [49.250-59.250 U/L]) was similar to value for Group II (56.400 U/L, IR: [55.700-61.200 U/L]), which received gentamicin and the garlic diet $(\mathrm{p}=0.161)$. However, the median NAG value for Group I (77.030 U/L, IR:
[65.750-87.130 U/L]), which received gentamicin and the normal diet, was found to be statistically significantly higher $(\mathrm{p}=0.010)$ than the value for the control group (Group III) (Table-2).

Serum Samples: A comparison of Group I and II with Group III (the control group) with respect to urea, creatinine, total protein, and cystatin levels revealed no statistically significant differences $(p>0.05)$ (Table-2).

However, the median cystatin value for Group II (1.360 U/L, IR: [0.900-1.630 U/L]), which received gentamicin and the garlic diet, was found to be statistically significantly lower than the value for Group I (2.240 U/L, IR: [1.760-2.510 U/L]), which received the normal diet $(p=0.015)(\mathrm{Ta}-$ ble-2) (Mean cystatin values for groups were calculated as: $2.03 \pm 0.64 \mathrm{U} / \mathrm{L}$ in Group I, $1.24 \pm 0.47$ $\mathrm{U} / \mathrm{L}$ in Group II, and $1.79 \pm 0.74 \mathrm{U} / \mathrm{L}$ in Group III).

\section{DISCUSSION}

NAG is a high molecular weight enzyme, which, under normal circumstances, cannot cross into the glomerular filtrate. For this reason, the

Table 1 - Urine sample results according to groups.

\begin{tabular}{|c|c|c|c|c|c|c|}
\hline & \multicolumn{6}{|c|}{ Groups } \\
\hline & \multicolumn{2}{|r|}{ I } & \multicolumn{2}{|r|}{ II } & \multicolumn{2}{|r|}{ III } \\
\hline & Median & IR & Median & IR & Median & IR \\
\hline Volume (mL) & 1.150 & $1.075-1.288$ & 1.400 & $1.225-1.475$ & 1.300 & $1.050-1.475$ \\
\hline Microalbumin (mg/L) & 3.350 & $1.750-6.750$ & 3.100 & $2.800-5.250$ & 3.150 & $2.700-4.900$ \\
\hline Creatinin $(\mathrm{mg} / \mathrm{dL})$ & 51.600 & $30.350-52.500$ & 39.600 & $39.000-40.100$ & 39.000 & $38.000-39.600$ \\
\hline $\mathrm{Na}(\mathrm{mmol} / \mathrm{L})$ & 27.000 & $24.000-35.000$ & 26.500 & $26.000-27.000$ & 26.000 & $25.000-27.500$ \\
\hline $\mathrm{K}(\mathrm{mmol} / \mathrm{L})$ & 187.200 & $106.000-191.950$ & 182.300 & $180.750-183.400$ & 182.450 & $179.950-184.350$ \\
\hline$P(m g / d L)$ & 143.000 & $82.000-146.150$ & 92.400 & $90.800-94.950$ & 92.000 & $90.500-95.800$ \\
\hline $\mathrm{Cl}(\mathrm{mmol} / \mathrm{L})$ & 50.500 & $20.500-53.000$ & 28.000 & $28.000-28.000$ & 28.000 & $27.000-31.000$ \\
\hline $\mathrm{pH}$ & 7.000 & $6.000-7.000$ & 7.000 & $7.000-7.000$ & 7.000 & $5.500-7.000$ \\
\hline NAG & $77.030^{*}$ & $65.750-87.130$ & 56.400 & $55.700-61.200$ & $52.050^{*}$ & $49.250-59.250$ \\
\hline
\end{tabular}

IR = Interquartile Ranges

* Statistically significant difference between Group I and Group III ( $p=0.010)$ 
Table 2 - Blood sample results according to groups.

\begin{tabular}{|c|c|c|c|c|c|c|c|c|c|}
\hline & \multicolumn{9}{|c|}{ Groups } \\
\hline & \multicolumn{3}{|c|}{ I } & \multicolumn{3}{|c|}{ II } & \multicolumn{3}{|c|}{ III } \\
\hline & $\begin{array}{c}\text { Mean } \pm \\
\text { SD }\end{array}$ & Median & IR & $\begin{array}{c}\text { Mean } \pm \\
\text { SD }\end{array}$ & Median & IR & $\begin{array}{c}\text { Mean } \pm \\
\text { SD }\end{array}$ & Median & IR \\
\hline $\begin{array}{l}\text { Creatinin } \\
(\mathrm{mg} / \mathrm{dL})\end{array}$ & $\begin{array}{c}0.34 \pm \\
0.06\end{array}$ & 0.350 & $0.350-0.450$ & $\begin{array}{c}0.31 \pm \\
0.0\end{array}$ & 0.320 & $0.270-0.370$ & $\begin{array}{c}0.31 \pm \\
0.03\end{array}$ & 0.350 & $0.310-0.365$ \\
\hline $\begin{array}{l}\text { Urea } \\
(\mathrm{mg} / \mathrm{dL})\end{array}$ & $\begin{array}{c}66.25 \pm \\
40.81\end{array}$ & 50.000 & $44.500-70.000$ & $\begin{array}{c}46.25 \pm \\
5.28\end{array}$ & 44.000 & $42.000-51.000$ & $\begin{array}{r}43.75 \\
\pm 6.36\end{array}$ & 46.000 & $37.500-48.500$ \\
\hline $\begin{array}{l}\text { Total protein } \\
(\mathrm{g} / \mathrm{dL})\end{array}$ & $\begin{array}{c}5.83 \pm \\
0.79\end{array}$ & 5.600 & $5.200-6.450$ & $\begin{array}{l}6.5 \pm \\
0.29\end{array}$ & 6.400 & $6.250-6.800$ & $\begin{array}{c}5.77 \pm \\
0.70\end{array}$ & 5.400 & $5.300-6.550$ \\
\hline $\begin{array}{l}\text { Cystatin } \\
\text { (mg/L) }\end{array}$ & $\begin{array}{c}2.03 \pm \\
0.64\end{array}$ & $2.240^{*}$ & $1.760-2.510$ & $\begin{array}{c}1.24 \pm \\
0.47\end{array}$ & $1.360^{*}$ & $0.900-1.630$ & $\begin{array}{c}1.79 \pm \\
0.74\end{array}$ & 2.240 & $0.900-2.340$ \\
\hline
\end{tabular}

source of NAG in urine is the proximal tubule cells. As an indicator of necrosis, NAG excretion via urine increases in case of kidney diseases that affect the proximal tubule cells, or in case of nephrotoxic drug use (9). In our study, the excretion of NAG in Group I rats, in which we induced nephrotoxicity and administered a normal diet, has increased in comparison to the control group ( $\mathrm{p}=0.010)$. In Group II rats, in which we induced nephrotoxicity and administered a garlic diet, the level of NAG excretion was, due to the antioxidant effects of garlic, found to be similar to the levels observed in the control group. It was shown that urinary NAG level is a sensitive parameter for the early assessment of subclinical nephrotoxicity (10). Why only NAG values differed in the groups can be explained by the fact that, in comparison with other parameters, increased urinary NAG levels show nephrotoxicity in a still early phase.

The cystatin $\mathrm{C}$ protein is a member of the cysteine protease family that is produced at a constant rate by cells with nucleus. Due to its low molecular weight, cystatin C filters freely through the glomeruli, with its reabsorption and metabolism taking place mainly in the proximal tubule (11). For this reason, cystatin C can be used as an indicator during the evaluation of renal function (12). In our study, we observed that the level of cystatin C in Group I rats (median: 2.240 U/L, IR: [1.760-2.510 U/L]), in which we induced nephrotoxicity and administered a normal diet, was higher in comparison to the Group II rats (median: $1.360 \mathrm{U} / \mathrm{L}, \mathrm{IR}:$ [0.900-1.630 U/L]), in which we induced nephrotoxicity and administered a garlic diet.

The advantages of aminoglycosides include their rapid and high antibacterial effect, low potential for the development of resistance, synergistic effect with beta-lactam antibiotics, and low cost. However, their clinical use is limited by their side effects, and especially their high nephrotoxicity by reactive oxygen species and oxidative stress (1). Gentamicin nephrotoxicity has been reproduced in various experimental animal models (mice, rat and rabbit) (13-15), and numerous agents $(1,16,17)$ have been studied in order to investigate their ability to reduce this nephrotoxicity. As reported by Badreldin HA et al., medicinal plants extracts, compounds from aged garlic, withania somnifera, sesame oil (sesamum indicum, antioxidant vitamins C 
and E), nitric oxide, and dihydropyridine calcium channel blockers are some of the agents that have been studied (18).

The pharmacological activity of garlic stems from its high organosulfur content (19). It is known that garlic has a preventive effect against immune disorders, intestinal irregularity, atherosclerosis, cancer, arthritis and respiratory infections, and that it also has hypolipidemic, hypoglycemic, antihypertensive and antithrombolytic effects (20-22). The most important factor that contributes to garlic's protective properties against disease is its anti-oxidant effect (4). Rietz et al. have demonstrated that feeding 2\% of pulverized wild garlic for 8 weeks conferred a cardioprotective effect against ischemia and reperfusion (23). Malki et al. have reported that garlic triggered apoptosis in human breast cancer cells (24). Numagami et al. have demonstrated that S-allylcysteine, a compound of garlic, prevented lipid peroxidation and neuronal damage in rat brain ischemia (25). Pedraza-Chaverri et al. have reported that feeding $2 \%$ garlic reduced the generation of renal $\mathrm{H}_{2} \mathrm{O}_{2}$ (26). In addition, Banerjee et al. have demonstrated that garlic confers a protective effect to kidney and liver cells against oxidative damage by increasing the levels of endogenous antioxidant enzymes such as superoxide dismutase and catalase (21).

In an experimental study they have conducted, Pedraza-Chaverri et al. have induced kidney damage and oxidative stress in rats by administering gentamicin. It was demonstrated that, between the group provided with a garlic diet and the control group, there were no significant differences in the plasma glutathione peroxidase enzyme activities, as well as the kidney superoxide dismutase, glutathione peroxidase and kidney catalase enzyme activities (7). In another study, Maldonado et al. have investigated the antioxidant effects of garlic in experimental animal models by inducing nephrotoxicity with gentamicin. They reported that aged garlic extracts prevented an increase in carbonyl and nitrotyrosine levels in the renal cortex, and that the extracts also precluded a decrease in the activity of antioxidant enzymes (manganese-containing superoxide dismutase, glutathione peroxidase, glutathione reductase) (6).
To the best of our knowledge, this study is the first to use cystatin $C$ in addition to NAG for demonstrating gentamicin-related nephrotoxicity. This study might serve as a guide for determining and, if necessary, for taking early measures against nephrotoxicity that might develop in humans at normal usage doses. For this reason, it is necessary to further confirm the findings of this study within the context of human clinical studies.

Limitations of our study are the small sample size and the fact that no more control groups were included. No gentamicine and garlic diet group might have rendered the study more powerful.

\section{CONCLUSIONS}

Using parameters NAG in urine samples and cystatin $C$ in serum samples we showed the effect of $4 \%$ garlic supplemented diet for preventing nephrotoxicity induced by gentamicin in rats. Following the completion of future clinical studies, we believe that, in order to prevent nephrotoxicity, garlic extracts can be provided to gentamicin-receiving patients.

\section{CONFLICT OF INTEREST}

None declared.

\section{REFERENCES}

1. Ali BH: Agents ameliorating or augmenting experimental gentamicin nephrotoxicity: some recent research. Food Chem Toxicol. 2003; 41: 1447-52.

2. Yanagida C, Ito K, Komiya I, Horie T: Protective effect of fosfomycin on gentamicin-induced lipid peroxidation of rat renal tissue. Chem Biol Interact. 2004; 148: 139-47.

3. Ademuyiwa 0, Ngaha E0, Ubah FO: Vitamin E and selenium in gentamicin nephrotoxicity. Hum Exp Toxicol. 1990; 9: 281-8.

4. Atmaca G: Sarımsagın ve tiol içeren bazı bilesiklerin antioksidatif etkileri. Trakya Üniv Tıp Fak Derg. 2003; 20: 54-60.

5. Pedraza-Chaverrí J, González-Orozco AE, Maldonado PD, Barrera D, Medina-Campos ON, Hernández-Pando R: Diallyl disulfide ameliorates gentamicin-induced oxidative stress and nephropathy in rats. Eur J Pharmacol. 2003; 473: 71-8. 
6. Maldonado PD, Barrera D, Rivero I, Mata R, MedinaCampos ON, Hernández-Pando $\mathrm{R}$, et al.: Antioxidant S-allylcysteine prevents gentamicin-induced oxidative stress and renal damage. Free Radic Biol Med. 2003; 35: 317-24.

7. Pedraza-Chaverrí J, Maldonado PD, Medina-Campos ON, Olivares-Corichi IM, Granados-Silvestre MA, Hernández-Pando R, et al.: Garlic ameliorates gentamicin nephrotoxicity: relation to antioxidant enzymes. Free Radic Biol Med. 2000; 29: 602-11.

8. Maldonado PD, Barrera D, Medina-Campos ON, Hernández-Pando R, Ibarra-Rubio ME, Pedraza-Chaverrí $\mathrm{J}$ : Aged garlic extract attenuates gentamicin induced renal damage and oxidative stress in rats. Life Sci. 2003; 73 : 2543-56.

9. Kavukçu S, Soylu A, Türkmen M: The clinical value of urinary $\mathrm{N}$-acetyl-beta-D-glucosaminidase levels in childhood age group. Acta Med Okayama. 2002; 56: 7-11.

10. Duan SB, Wu HW, Luo JA, Liu FY: Assessment of renal function in the early stages of nephrotoxicity induced by iodinated contrast media. Nephron. 1999; 83: 122-5.

11. Borges RL, Hirota AH, Quinto BM, Ribeiro AB, Zanella MT, Batista MC: Is cystatin $C$ a useful marker in the detection of diabetic kidney disease? Nephron Clin Pract. 2010; 114: c127-34.

12. Thomas C, Thomas L: Renal failure--measuring the glomerular filtration rate. Dtsch Arztebl Int. 2009; 106: 849-54.

13. Kelly KJ, Kluve-Beckerman B, Zhang J, Dominguez JH: Intravenous cell therapy for acute renal failure with serum amyloid A protein-reprogrammed cells. Am J Physiol Renal Physiol. 2010; 299: F453-64.

14. Bushma KM, Kizyukevich LS, Bushma MI, Nechiporenko NA: Role of individual structural features of rabbit kidneys in the predisposition to gentamicin nephrotoxicity. Bull Exp Biol Med. 2004;138: 482-6.

15. Ali BH, Al-Salam S, Al-Husseini I, Nemmar A: Comparative protective effect of $\mathrm{N}$-acetyl cysteine and tetramethylpyrazine in rats with gentamicin nephrotoxicity. J Appl Toxicol. 2009; 29: 302-7.

16. Ali BH: Gentamicin nephrotoxicity in humans and animals: some recent research. Gen Pharmacol. 1995; 26: 1477-87.

17. Koyner JL, Sher Ali R, Murray PT: Antioxidants. Do they have a place in the prevention or therapy of acute kidney injury? Nephron Exp Nephrol. 2008; 109: e109-17.
18. Ali BH, Al Za'abi M, Blunden G, Nemmar A: Experimental gentamicin nephrotoxicity and agents that modify it: a mini-review of recent research. Basic Clin Pharmacol Toxicol. 2011; 109: 225-32.

19. Kerckhoffs DA, Brouns F, Hornstra G, Mensink RP: Effects on the human serum lipoprotein profile of beta-glucan, soy protein and isoflavones, plant sterols and stanols, garlic and tocotrienols. J Nutr. 2002; 132: 2494-505.

20. Amagase $\mathrm{H}$, Petesch BL, Matsuura H, Kasuga S, Itakura $\mathrm{Y}$ : Intake of garlic and its bioactive components. J Nutr. 2001; 131: 955S-62S.

21. Banerjee SK, Maulik M, Manchanda SC, Dinda AK, Das TK, Maulik SK: Garlic-induced alteration in rat liver and kidney morphology and associated changes in endogenous antioxidant status. Food Chem Toxicol. 2001; 39: 793-7.

22. Rahman K, Lowe GM: Garlic and cardiovascular disease: a critical review. J Nutr. 2006; 136: 736S-40.

23. Rietz B, Isensee $H$, Strobach $H$, Makdessi S, Jacob R: Cardioprotective actions of wild garlic (allium ursinum) in ischemia and reperfusion. Mol Cell Biochem. 1993; 119: 143-50.

24. Malki A, El-Saadani M, Sultan AS: Garlic constituent diallyl trisulfide induced apoptosis in MCF7 human breast cancer cells. Cancer Biol Ther. 2009; 8: 2175-85.

25. Numagami $Y$, Sato S, Ohnishi ST: Attenuation of rat ischemic brain damage by aged garlic extracts: a possible protecting mechanism as antioxidants. Neurochem Int. 1996; 29: 135-43.

26. Pedraza-Chaverrí J, Granados-Silvestre MD, MedinaCampos ON, Maldonado PD, Olivares-Corichi IM, IbarraRubio ME: Post-transcriptional control of catalase expression in garlic-treated rats. Mol Cell Biochem. 2001; 216: 9-19.

$$
\begin{array}{r}
\text { Correspondence address: } \\
\text { Omer Bayrak } \\
\text { University of Gaziantep, School of Medicine, } \\
\text { Department of Urology } \\
\text { Gaziantep, 27310, Turkey } \\
\text { Fax: + 90 342 360-3998 } \\
\text { E-mail: dromerbayrak@yahoo.com }
\end{array}
$$

